\title{
Sequence-Controlled Polymerization-Induced Self-Assembly
}

\author{
Lei Wang, Yi Ding, Qizhou Liu, Qingqing Zhao, Xinchao Dai, Xinhua Lu and Yuanli Cai* \\ State-Local Joint Engineering Laboratory of Novel Functional Polymeric Materials, College of Chemistry, Chemical Engineering and \\ Materials Science, Soochow University, Suzhou 215123, China
}

\section{Supporting Information}

Instrumentation. Visible light at $\mathrm{I}_{420 \mathrm{~nm}}=0.20 \mathrm{~mW} / \mathrm{cm}^{2}$ was obtained from a home-made photochemistry system equipped with $400 \mathrm{~W}$ mercury lamp, JB400 filters, ventilator and UV-A radiometer (420 nm detector). Polymer products were freeze-dried in a Labconco Freezone2.5L freeze-drier. The solution $\mathrm{pH}$ was probed using a FE20 digital $\mathrm{pH}$-meter.

Characterization. $U V$-Vis Spectroscopy was performed on a Shimadzu UV-1800 spectrometer. ${ }^{1} H$ NMR Spectroscopy was conducted on INOVA $400 \mathrm{MHz}$ NMR instrument. Aqueous Size Exclusion Chromatography (aqueous SEC) was conducted on a Waters1515 GPC setup equipped with refractive index detector and a column set $\left(2 \times \mathrm{PL}\right.$ aquagel-OH Mixed-M) using degassed buffer eluent $\left(0.20 \mathrm{M} \mathrm{NaNO}_{3}, 0.01 \mathrm{M} \mathrm{NaH}_{2} \mathrm{PO}_{4}\right.$, at $\mathrm{pH}$ 9.0). PEG standards (Agilent, $0.985-16.0 \mathrm{~kg} / \mathrm{mol}$ ) were used for calibration. The calibration and analysis were conducted at a flow rate of $1.0 \mathrm{~mL} / \mathrm{min}$ at $30^{\circ} \mathrm{C}$. Reaction solution of $\mathrm{PEG}_{45}-\mathrm{PAMPS}_{\mathrm{m}}$ block copolymer was diluted in the buffer to $2.0 \mathrm{mg} / \mathrm{mL}$ and passed through Titan PES $0.45 \mu \mathrm{m}$ filter before SEC studies. N,N-Dimethylformamide (DMF) SEC was conducted on a PL-GPC220 system equipped with refractive index detector and a column set $(2 \times$ PLGel MIXED-B + $1 \times$ PLGel MIXED-D). DMF that contained 10.0 mM LiBr was used as eluent. PMMA standards (Agilent, $1.95-1048.0 \mathrm{kDa}$ ) was used for calibration. The calibration and analysis were conducted at a flow rate of $1.0 \mathrm{~mL} / \mathrm{min}$ at $80^{\circ} \mathrm{C}$. To inspect the blocking efficiency of PEG-TTC macro-CTA, solution after chain extension of 2-hydroxypropylmethacrylamide (HPMA) monomer was freeze-dried. Solids was dissolved into DMF and filtered using Millipore Millex-FG $0.2 \mu \mathrm{m}$ filter prior to SEC studies. To study the kinetics of PEG-TTC macro-CTA mediated RAFT polymerization of AEAM monomer, $\mathrm{NH}_{3}{ }^{+}$-motif was converted into nonionic tertiary amino groups by reaction with methyl acrylate in the presence of trimethylamine and tributylphosphine in methanol in the dark. ${ }^{1}$ The solution was passed through silica column. After rotary evaporation, solids was dissolved into DMF, passed through $0.2 \mu \mathrm{m}$ filter for DMF SEC studies. Dynamic Light Scattering (DLS) was performed on a Brook-haven BI-200SM setup equipped with $22 \mathrm{~mW}$ He-Ne laser $(\lambda=633 \mathrm{~nm})$, BI-200SM goniometer and BI-TurboCorr digital correlator. Sample cell was controlled at $25^{\circ} \mathrm{C}$ and measured at $90^{\circ}$. The intensity-average hydrodynamic diameter $\left(D_{\mathrm{h}}\right)$ and dispersity (PDI) were determined by cumulants analysis in CONTIN routine. Data were averaged over 5 runs. The $\zeta$ potential value was determined by Aqueous Electrophoresis using a Malvern Zetasizer Nano-ZS90 instrument. Sample for aqueous electrophoresis and DLS studies was prepared by dilution of the dispersion to $2.0 \mathrm{mg} / \mathrm{mL}$ at $\mathrm{pH}$ 2.5. Transmission Electron Microscopy (TEM) was performed on a Hitachi HT7700 transmission electron microscope at an accelerating voltage of $120 \mathrm{kV}$. TEM sample was prepared as follows. The dispersion was diluted in water at $0{ }^{\circ} \mathrm{C}$ and $\mathrm{pH} 2.5$ to $1.0 \mathrm{mg} / \mathrm{mL}$. A drop was dripped onto a carbon-film coated copper grid. Sample-loaded grid was immersed in liquid nitrogen and frozen to $-170^{\circ} \mathrm{C}$ in a home-made cryo-box for $0.5 \mathrm{~h}$, freeze-dried under reduced pressure and shifted to a drying desiccator before TEM studies. Number-average diameter $\left(D_{\mathrm{n}}\right.$, TEM $)$ was determined by the statistical analysis using Nano Measurer 1.2 software program. Atomic Force Microscopy (AFM) was conducted on a Bruker Multimode 8 microscope operated in a peak force quantitative nanomechanical mode using SCANASYST-AIR probe. The silicon wafer was immersed into piranha solution at $80^{\circ} \mathrm{C}$ for $1.5 \mathrm{~h}$, rinsed with anhydrous ethanol under ultrasonic irrigation. AFM sample preparation on a clean silicon wafer was carried out under the procedures described for TEM sample freeze-drying preparation.

Materials. 2-Aminoethylacrylamide hydrochloride (AEAM), ${ }^{2}$ 4-cyano-4-ethylsulfanylthiocarbonylsulfanylpentanoic acid (CEP), ${ }^{3}$ sodium phenyl-2,4,6-trimethylbenzoylphosphinate (SPTP), ${ }^{4}$ and 2-hydroxypropylmethacrylamide (HPMA) ${ }^{5}$ were synthesized according to literatures. PEG-TTC macro-CTA (TTC: trithiocarbonate) was prepared via the functionalization of mono-hydroxyl polyethylene glycol (PEG$\mathrm{OH}, 2.0 \mathrm{~kg} / \mathrm{mol}, \mathrm{DP}=45, Ð=1.03$, Sigma-Aldrich) with CEP. ${ }^{6}$ 2-Acrylamido-2-methylpropanesulfonic acid (AMPS, 99\%) monomer was purchased from Sigma-Aldrich. Deuterium oxide $\left(\mathrm{D}_{2} \mathrm{O}, 99.9 \% \mathrm{D}\right)$ and deuterchloric acid $\left(20 \% \mathrm{DCl}\right.$ in $\left.\mathrm{D}_{2} \mathrm{O}, 99.5 \% \mathrm{D}\right)$ from $\mathrm{J} \& \mathrm{~K}$; other reagents from Aladdin. Agents and solvents were used as received. Deionized water at a resistivity of $18.2 \mathrm{M} \Omega \mathrm{cm}$ was obtained from a Direct-Q $5 \mathrm{UV}$ Millipore system. 
PEG-TTC Blocking Efficiency. HPMA monomer (143.3 mg, $1.0 \mathrm{mmol})$ and PEG-TTC macro-CTA (28.2 mg, $0.0125 \mathrm{mmol})$ were dissolved in water $(305 \mathrm{mg})$ in a $10 \mathrm{~mL}$ reaction flask. SPTP initiator $(1.0 \% \mathrm{w} / \mathrm{w}$ in water; $100 \mathrm{mg}, 3.225 \mu \mathrm{mol})$ was added into the flask. The flask was sealed, immersed into water bath at $25^{\circ} \mathrm{C}$, bubbled with argon gas for $1 \mathrm{~h}$, and exposed to light for $1.5 \mathrm{~h}$. Reaction was stopped by exposure to air. ${ }^{1} \mathrm{H}$ NMR: $62 \%$ conversion. The solution was freeze-dried. DMF SEC studies unveiled $M_{\mathrm{n}}=3.7 \mathrm{~kg} / \mathrm{mol}$ and $Ð=1.03$ of PEG-OH, $M_{\mathrm{n}}=3.8$ $\mathrm{kg} / \mathrm{mol}$ and $Ð=1.02$ of PEG-TTC, $M_{\mathrm{n}}=11.0 \mathrm{~kg} / \mathrm{mol}$ and $Ð=1.08$ of PEG-PHPMA (Figure S1E). These demonstrate the high blocking efficiency of PEG-TTC macro-CTA.

ABC-Mode PIESA Protocol. AMPS monomer (93.0 mg, $0.406 \mathrm{mmol}$ ) and PEG-TTC (44.5 mg, 19.8 umol) were dissolved into water (397 $\mathrm{mg})$ in a $5 \mathrm{~mL}$ flask. SPTP initiator $(1.0 \mathrm{w} / \mathrm{w} \%$ in water; $153.5 \mathrm{mg} ; 4.95 \mu \mathrm{mol})$ was added into the flask. The solution was adjusted to $\mathrm{pH} 2.5$. The flask was sealed, immersed in water bath at $25{ }^{\circ} \mathrm{C}$, bubbled with argon in the dark for $1 \mathrm{~h}$, and exposed to light for $2.5 \mathrm{~h}$. Visible light was turned off. AEAM monomer (20\% w/w in water, $\mathrm{pH} 2.5 ; 302.5 \mathrm{mg}, 0.402 \mathrm{mmol})$ was added into the flask using a deoxygenated syringe. Sample was taken for ${ }^{1} \mathrm{H}$ NMR (>99\% AMPS conversion) and aqueous SEC studies $\left(M_{\mathrm{n}}=12.17 \mathrm{~kg} / \mathrm{mol}, \bigoplus=1.05\right)$. The solution was irradiated with light for $2.5 \mathrm{~h}$. Reaction was stopped by exposure to air. $\mathrm{A}_{45} \mathrm{~B}_{\mathrm{x}} \mathrm{C}_{\mathrm{x}}$ at $\mathrm{x}=22,25,30,40,45,50$, 55 were synthesized using above procedures, changing $[\text { monomer }]_{0} /[\text { PEG-TTC }]_{0}$ (x value). The final dispersions were characterized using ${ }^{1} \mathrm{H} \mathrm{NMR,} \mathrm{UV-vis} \mathrm{spectroscopy,} \zeta$-potential, DLS, TEM, and AFM.

AB(BC)-Mode PIESA Protocol. AMPS monomer (93.0 mg, $0.406 \mathrm{mmol}$ ), PEG-TTC (16.2 mg, $7.22 \mu \mathrm{mol}$ ) were dissolved in water (381 mg) in a $5 \mathrm{~mL}$ flask. SPTP initiator $(1.0 \mathrm{w} / \mathrm{w} \%$ in water; $55.9 \mathrm{mg} ; 1.8 \mu \mathrm{mol})$ was added into the flask. The solution was adjusted to $\mathrm{pH} 2.5$. The flask was sealed, immersed in water bath at $25^{\circ} \mathrm{C}$, bubbled with argon in the dark for $1 \mathrm{~h}$, and irradiated with light for 112 min. After turning off visible light, AEAM $(20 \% \mathrm{w} / \mathrm{w}$ in water, $\mathrm{pH} 2.5 ; 302 \mathrm{mg}, 0.401 \mathrm{mmol})$ was added into the flask. The solution was sampled for ${ }^{1} \mathrm{H}$ NMR studies (90\% AMPS conversion). The solution was irradiated with light for $2.5 \mathrm{~h}$ and exposed to air. Other $\mathrm{A}_{45} \mathrm{~B}_{\mathrm{x}}\left(\mathrm{B}_{55-\mathrm{x}} \mathrm{C}_{55}\right)$ were synthesized using above procedures but the zwitterionic copolymerization started at different first AMPS conversions. $A_{45} B_{x}\left(B_{100-x} C_{100}\right)$ were synthesized under above procedures but at $[\mathrm{AMPA}] /[\mathrm{AEAM}] /[\mathrm{PEG}-\mathrm{TTC}]=100: 100: 1$ and different first AMPS conversions. The final dispersions were characterized using ${ }^{1} \mathrm{H}$ NMR, UV-vis spectroscopy, $\zeta$-potential, DLS, TEM, and AFM studies.

AB(BC)-Mode PIESA Kinetics. AMPS monomer $(93.0 \mathrm{mg}, 0.406 \mathrm{mmol})$ and PEG-TTC ( $8.9 \mathrm{mg}, 3.96 \mu \mathrm{mol})$ were dissolved in water (378 $\mathrm{mg})$ in a $5 \mathrm{~mL}$ flask. SPTP initiator $(1.0 \mathrm{w} / \mathrm{w} \%$ in water; $30.7 \mathrm{mg} ; 0.99 \mu \mathrm{mol})$ was added into the flask. The solution was adjusted to $\mathrm{pH} 2.5$. The flask was sealed, immersed in water bath at $25^{\circ} \mathrm{C}$, and bubbled with argon in the dark for $1 \mathrm{~h}$. The solution was irradiated with light for 71 min. After turning off visible light, AEAM (20\% w/w in water, pH 2.5; $302 \mathrm{mg}, 0.401 \mathrm{mmol}$ ) was added into the solution. The solution was sampled for ${ }^{1} \mathrm{H}$ NMR studies. The mixture was irradiated with light. Reaction solution was sampled periodically, exposed to air, placed in the dark for ${ }^{1} \mathrm{H}$ NMR, UV-vis spectroscopy, $\zeta$-potential, DLS, and TEM characterizations. 

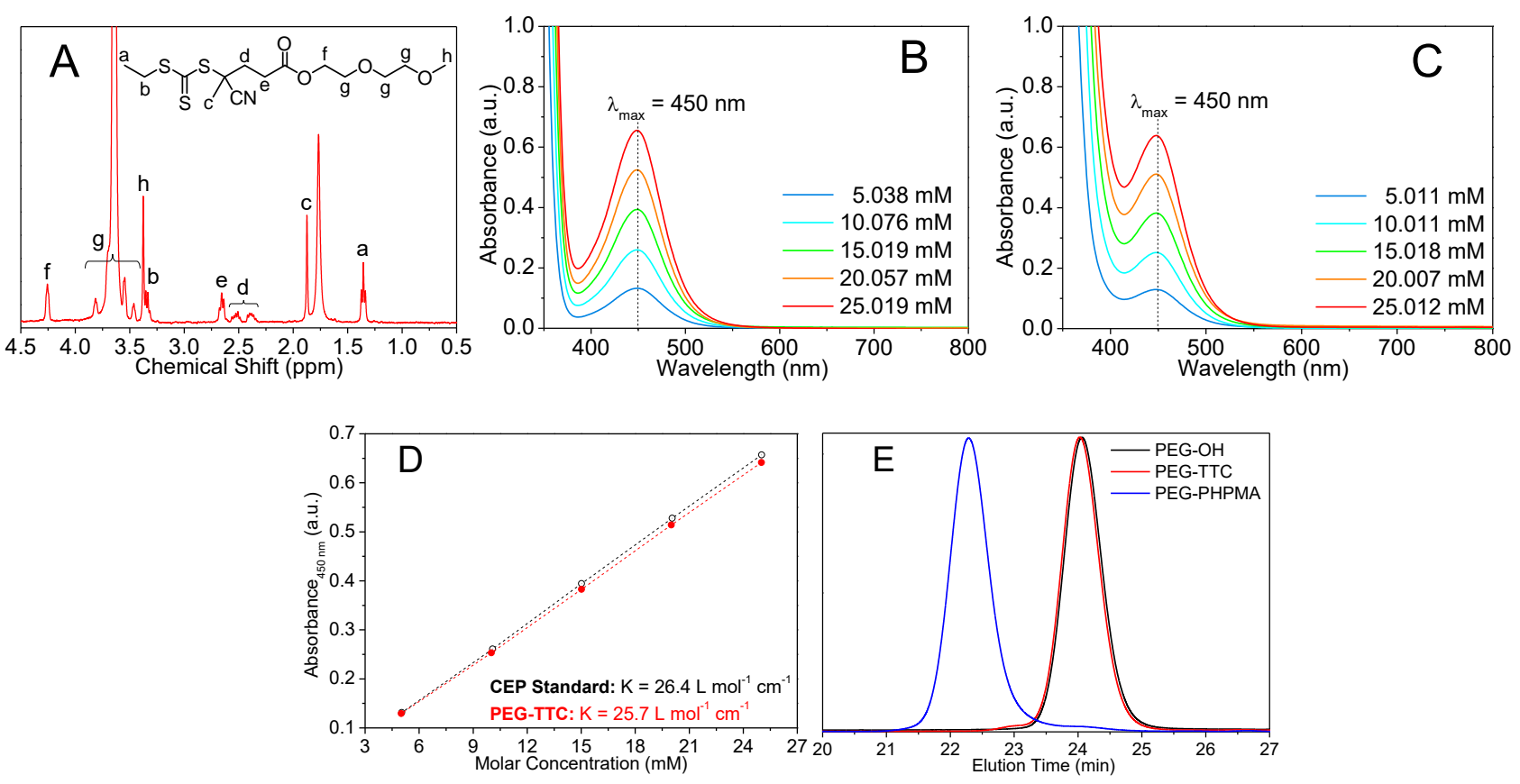

Figure S1. (A) ${ }^{1} \mathrm{H}$ NMR spectrum of PEG-TTC in which a 97\% TTC-functionalization was evaluated according to Equation S1. UV-vis spectra of (B) CEP standard and (C) PEG-TTC at labeled concentrations, in which apparent molar absorption coefficients (K) were evaluated based on the LambertBeer plots (D), and TTC-functionalization was calculated to be $(25.7 / 26.4) \times 100 \%=97 \%$. The high blocking efficiency was evidenced by $(\mathrm{E})$ the shift of SEC trace of a PEG-PHPMA copolymer synthesized via visible light initiated PEG-TTC mediated RAFT polymerization of HPMA monomer.

$$
\text { TTC Functionalization }=\frac{I_{b+h^{-}} \frac{2 \times I_{a}}{3}}{I_{a}} \times \mathbf{1 0 0} \%=\mathbf{9 7} \%
$$
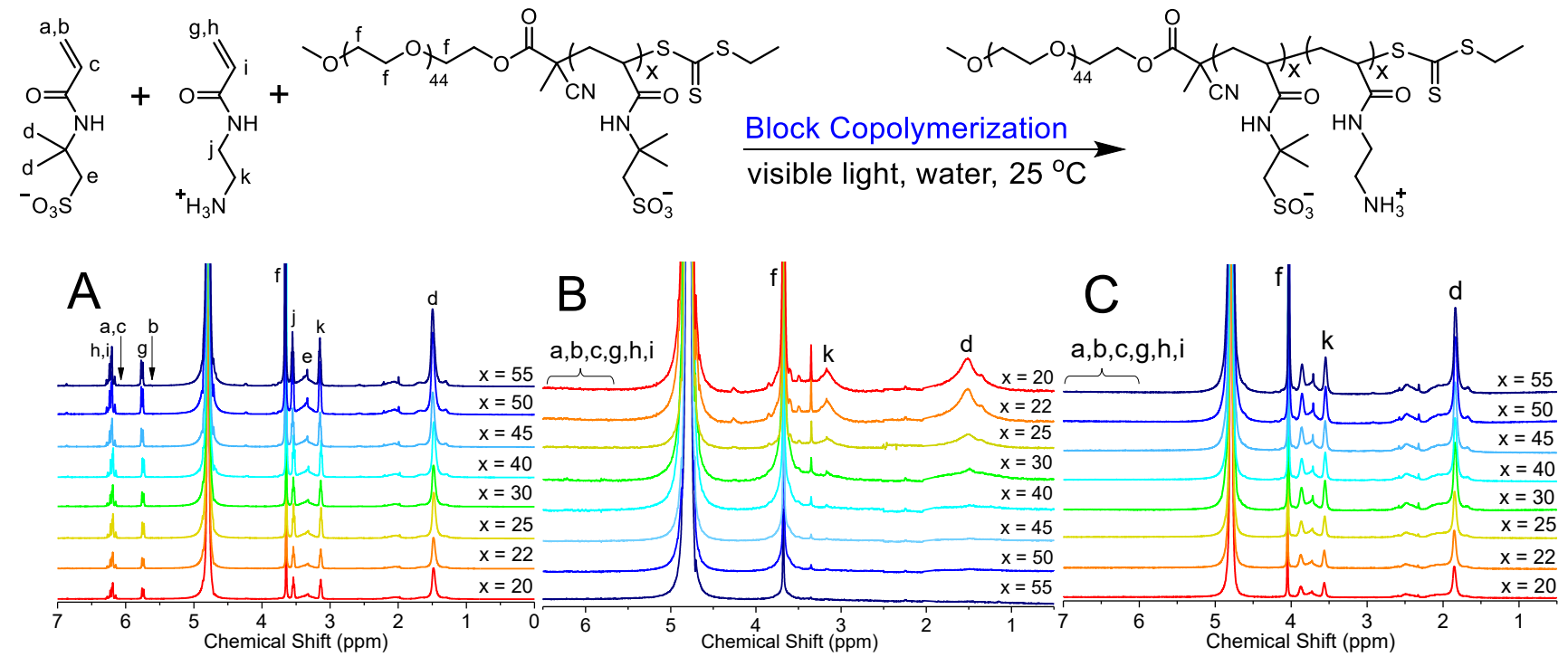

Figure S2. (A) ${ }^{1} \mathrm{H}$ NMR spectra of the intermediate solutions after the addition of AEAM monomer into completely polymerized AMPS monomer solution recorded in $\mathrm{D}_{2} \mathrm{O}$ at $\mathrm{pH} 2.5$, and those of the final dispersions after complete polymerization of $A E A M$ monomer recorded in $(\mathrm{B}) \mathrm{D}_{2} \mathrm{O}$ at $\mathrm{pH}$ 2.5 and $(\mathrm{C})$ the salted solutions at $4.5 \mathrm{M} \mathrm{NaCl}$ and $\mathrm{pH} 2.5$. 

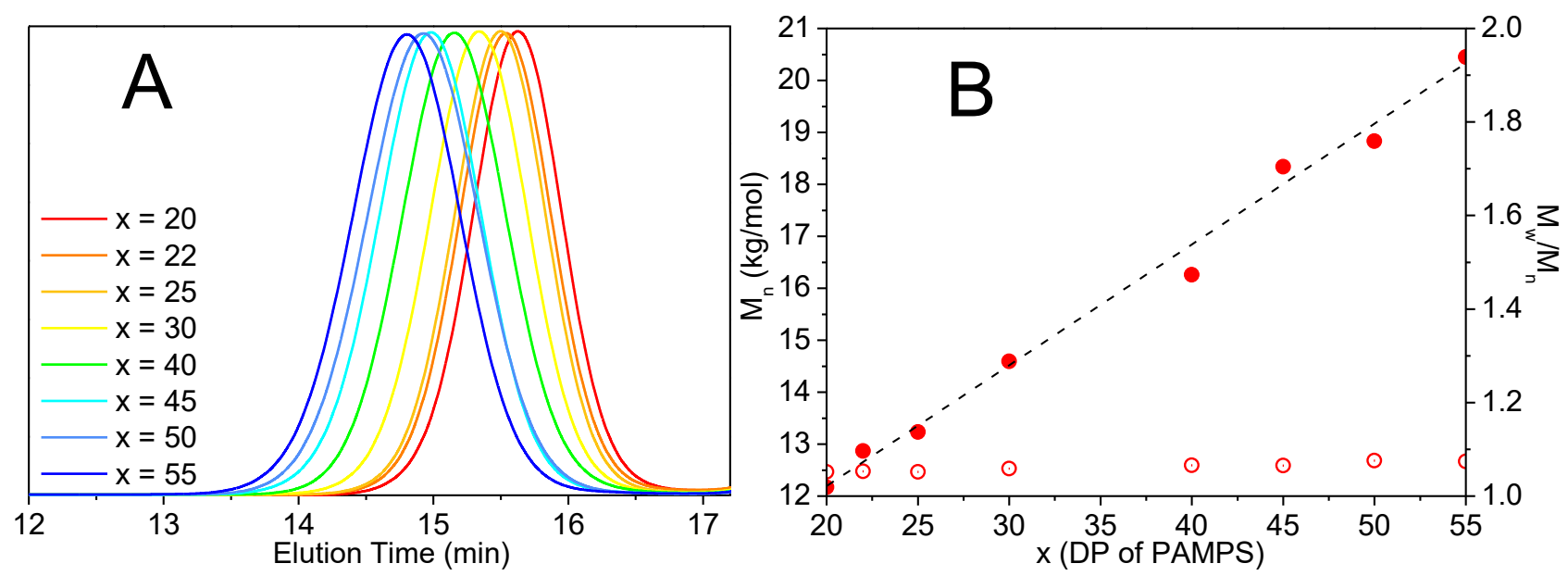

Figure S3. (A) Aqueous SEC traces of PEG 45 -PAMPS $x$ block copolymers at labeled $x$ values synthesized via visible light initiated PEG-TTC mediated RAFT polymerization of AMPS monomer. (B) The number-average molecular weight $\left(M_{n}\right)$ and dispersity $(\boxplus)$ of the block copolymers as a function of the $\mathrm{x}$ values.
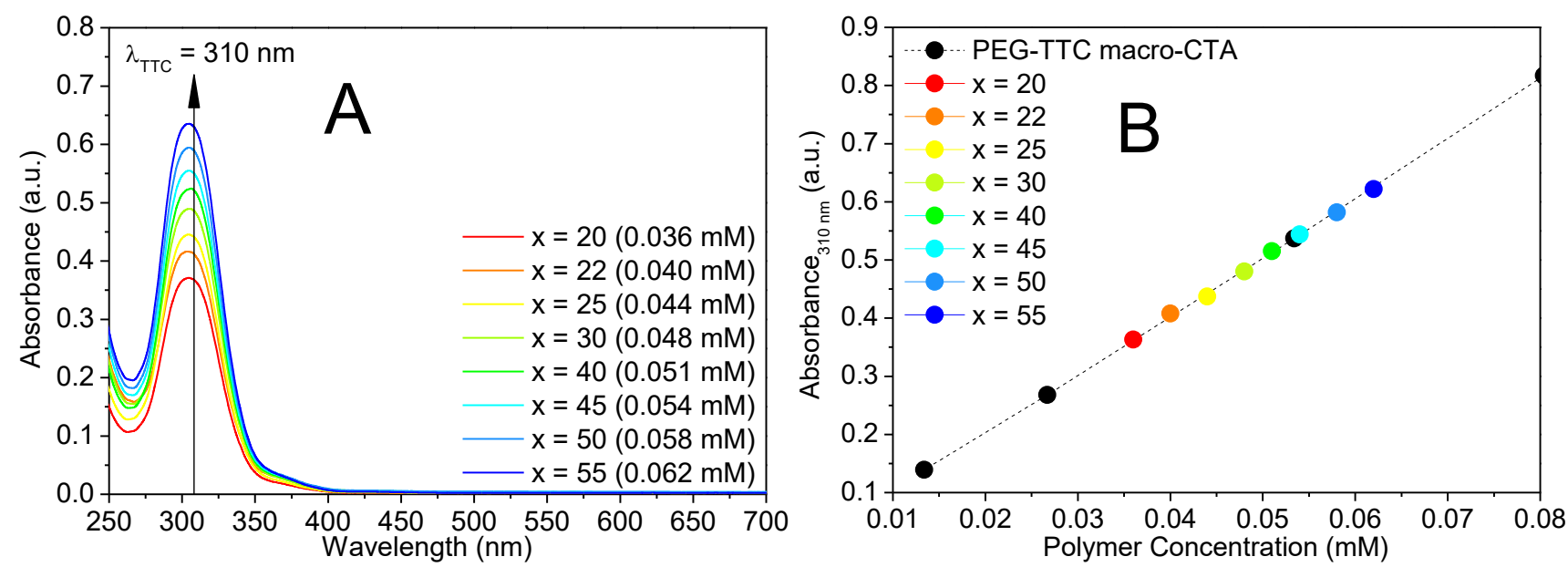

Figure S4. (A) UV-vis spectra of $\mathrm{A}_{45} \mathrm{~B}_{\mathrm{x}} \mathrm{C}_{\mathrm{x}}$ triblock copolymers in salted solution (4.5 M NaCl) at labelled polymer concentrations. (B) A Lambert-Beer plot to evaluate TTC functionalities of the triblock copolymers using PEG-TTC macro-CTA standard.

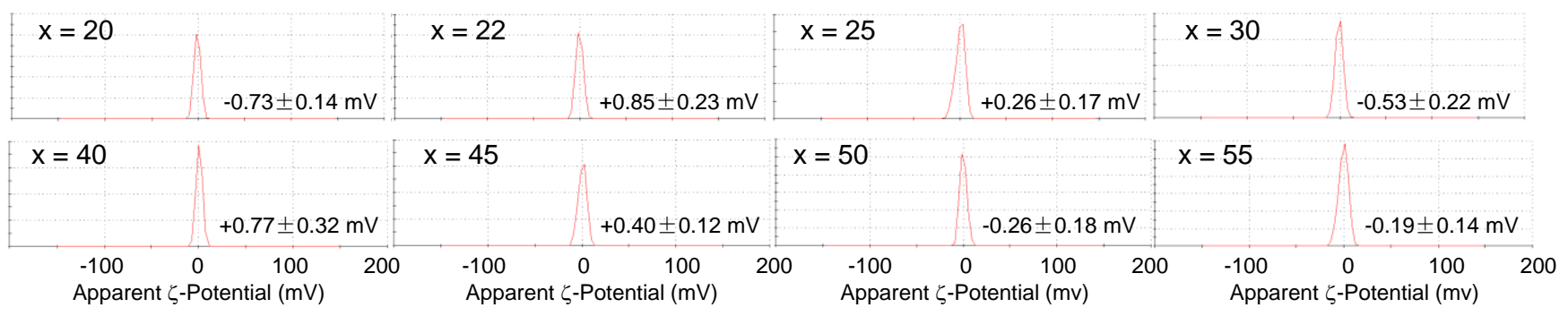

Figure S5. The $\zeta$-potential results of $\mathrm{A}_{45} \mathrm{~B}_{\mathrm{x}} \mathrm{C}_{\mathrm{x}}$ triblock copolymer PICs at labeled $\mathrm{x}$ values $(2.0 \mathrm{mg} / \mathrm{mL}$ in water, $\mathrm{pH} 2.5)$ synthesized via visible light initiated ABC-mode PIESA. 


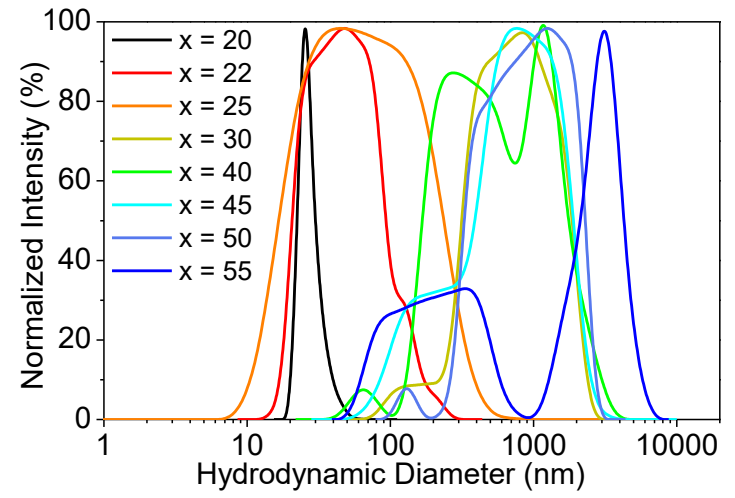

Figure S6. DLS results of the ABC-mode PIESA synthesized $A_{45} B_{x} C_{x}$ PICs at labeled $x$ values $(2.0 \mathrm{mg} / \mathrm{mL}$ in water at $\mathrm{pH} 2.5)$.
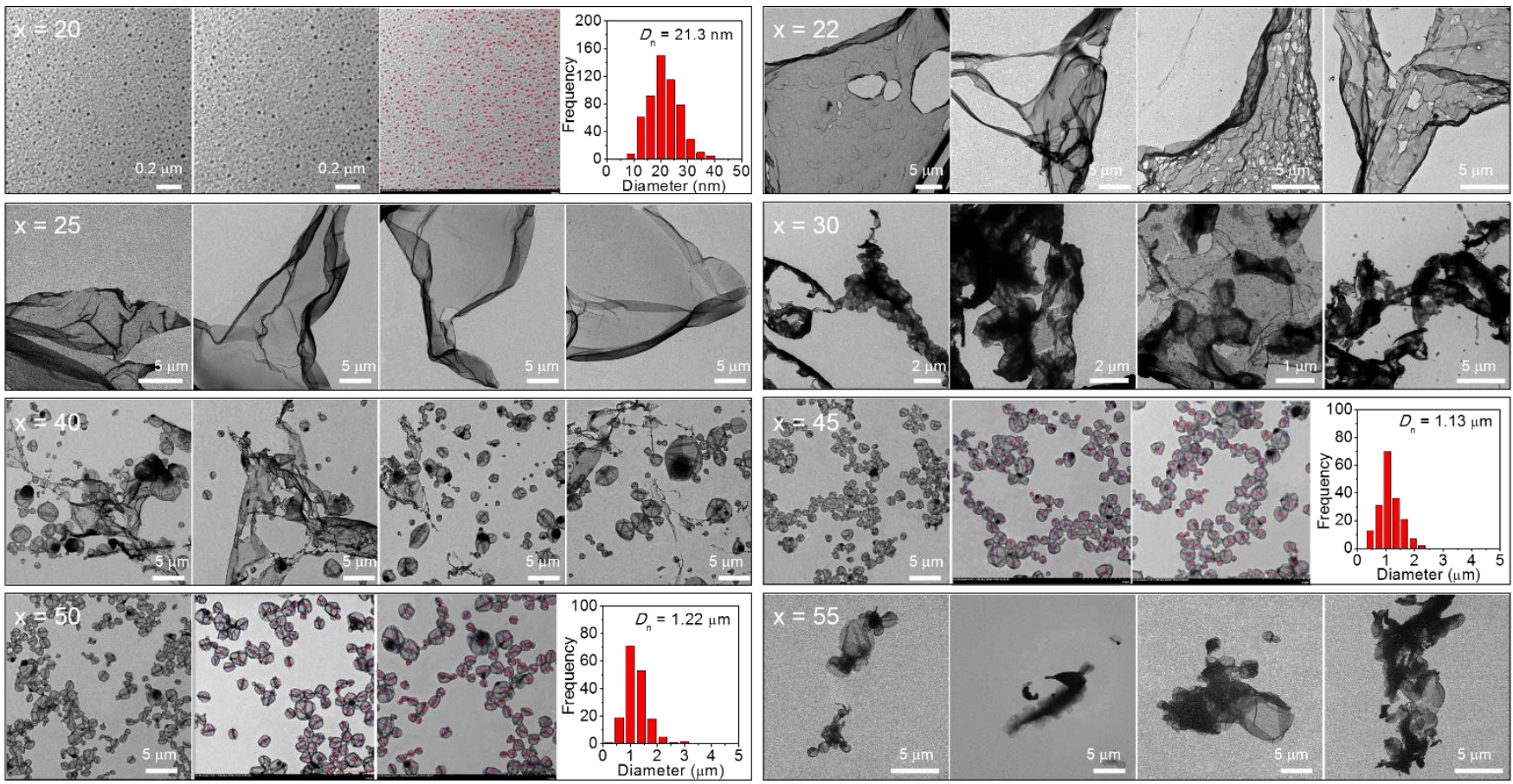

Figure S7. Additional TEM images and statistical analysis results of freeze-dried $A B C$-mode PIESA synthesized $A_{45} B_{x} C_{x}$ particles at the labeled $x$ values.

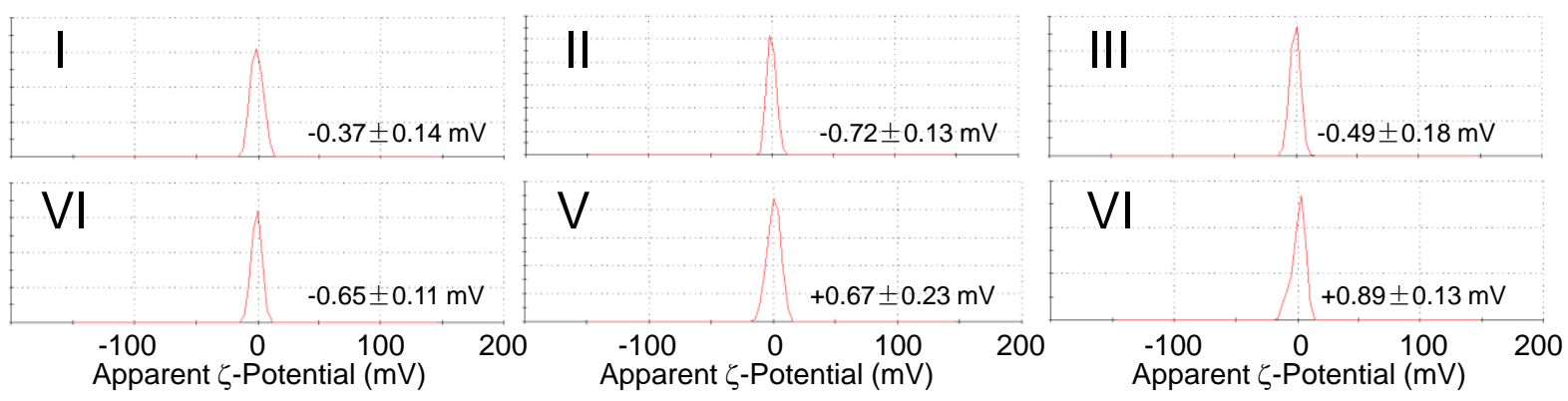

Figure S8. The $\zeta$-potential results of $\mathrm{AB}(\mathrm{BC})$-mode PIESA synthesized $\mathrm{A}_{45} \mathrm{~B}_{\mathrm{x}}\left(\mathrm{B}_{55-\mathrm{x}} \mathrm{C}_{55}\right)$ particles at $\mathrm{x}=52$ (I), 50 (II), 44 (III), 37 (IV), 33 (V), and $28(\mathrm{VI})(2.0 \mathrm{mg} / \mathrm{mL}$ in water at $\mathrm{pH} 2.5)$. 


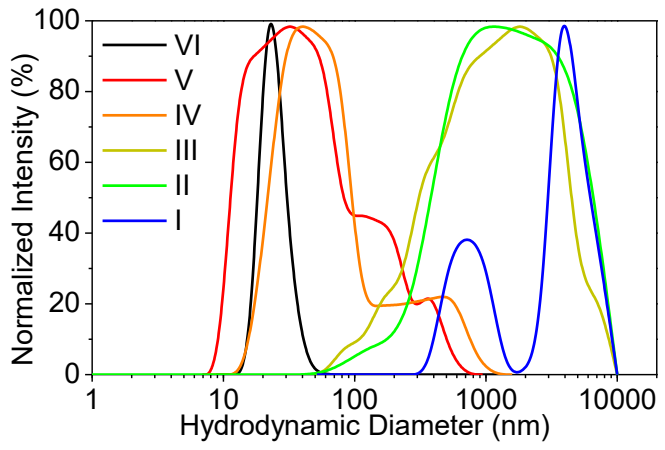

Figure S9. DLS results of the $\mathrm{AB}(\mathrm{BC})$-mode PIESA synthesized $\mathrm{A}_{45} \mathrm{~B}_{\mathrm{x}}\left(\mathrm{B}_{55-\mathrm{x}} \mathrm{C}_{55}\right)$ at $\mathrm{x}=52$ (I), 50 (II), 44 (III), 37 (IV), 33 (V), and 28 (VI) (2.0 $\mathrm{mg} / \mathrm{mL}$ in water at $\mathrm{pH} 2.5$ ).

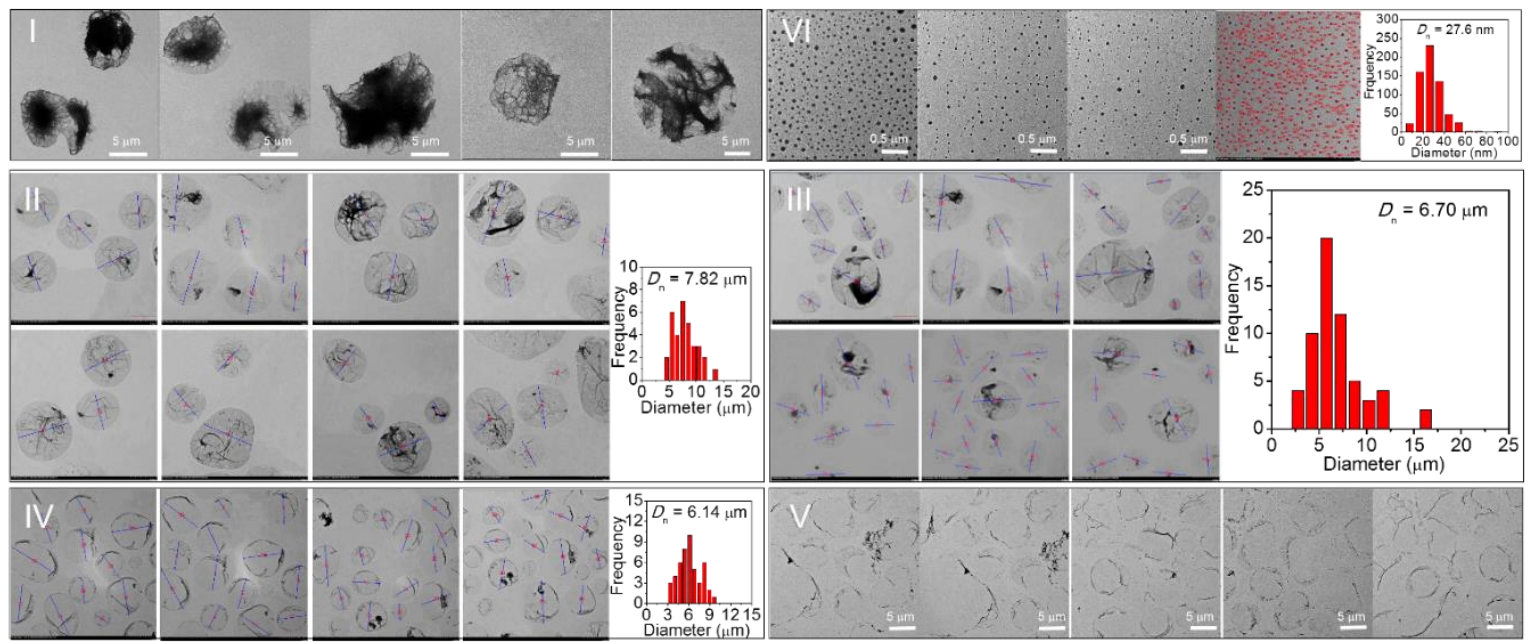

Figure S10. Additional TEM images and statistical analysis results of freeze-dried AB(BC)-mode PIESA synthesized $\mathrm{A}_{45} \mathrm{~B}_{\mathrm{x}}\left(\mathrm{B}_{55-\mathrm{x}} \mathrm{C}_{55}\right)$ at $\mathrm{x}=52(\mathrm{I}), 50$ (II), 44 (III), 37 (IV), 33 (V), and 28 (VI).

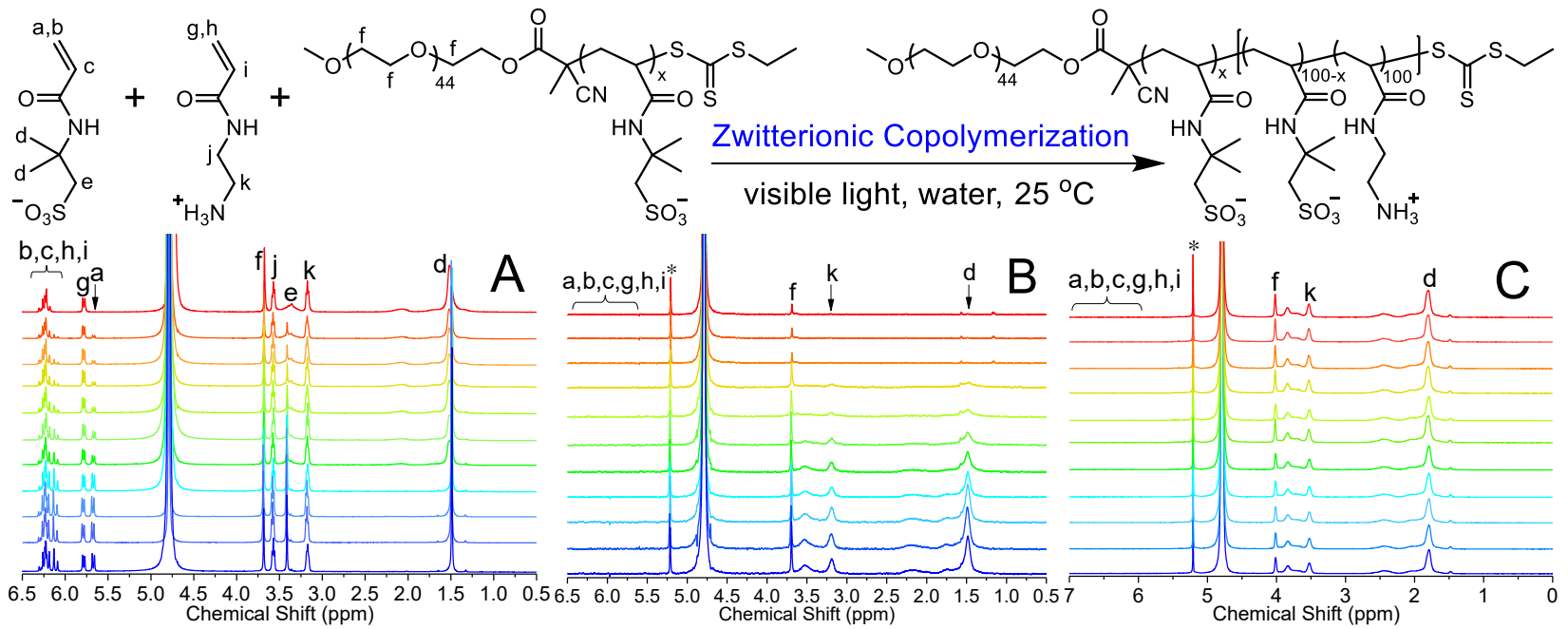

Figure S1 1. ${ }^{1} \mathrm{H}$ NMR spectra of (A) intermediate solutions after adding AEAM monomer at (from top to bottom) 100\%, 86\%, 75\%, 64\%, 55\%, 46\%, $36 \%, 25 \%, 13 \%, 8 \%$, and $0 \%$ AMPS conversions recorded in $\mathrm{D}_{2} \mathrm{O}, \mathrm{pH} 2.5$; those after zwitterionic copolymerization recorded in $\mathrm{D}_{2} \mathrm{O}(\mathbf{B})$ and $4.5 \mathrm{M}$ $\mathrm{NaCl}(\mathbf{C})$ in which 1,3,5-trioxane (asterisk) was added as calibration standard. 

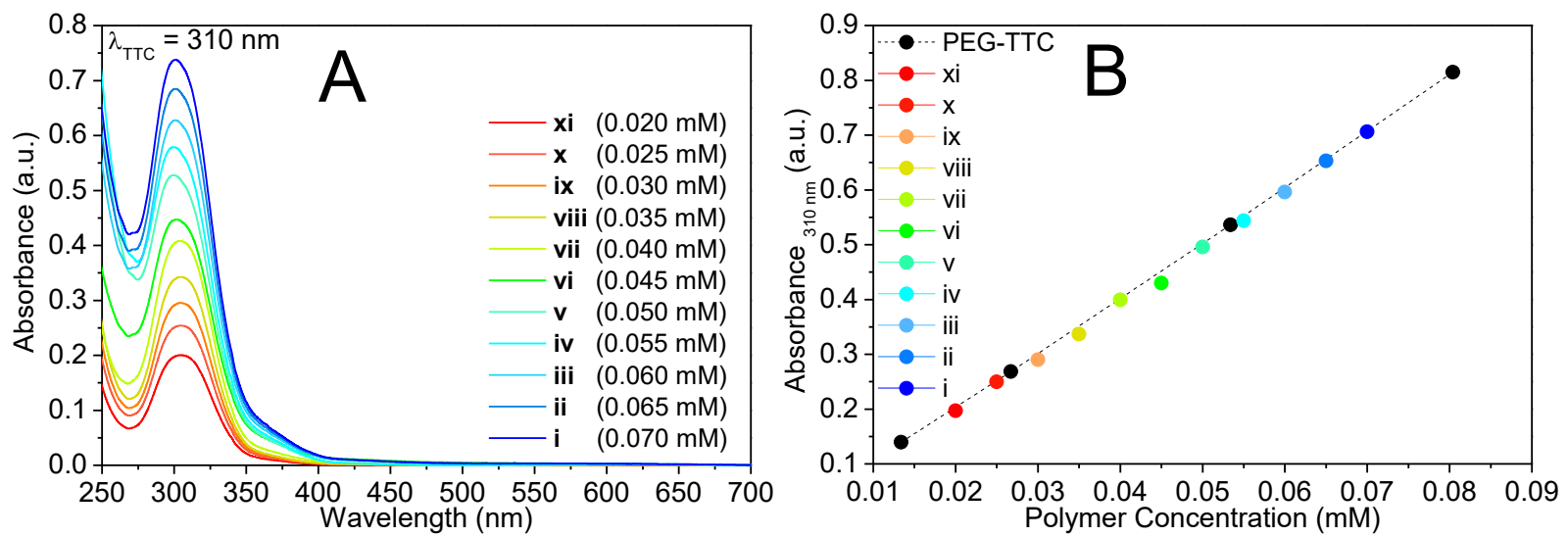

Figure S12. (A) UV-vis spectra of the $A B(B C)$-mode PIESA synthesized $A_{45} B_{x}\left(B_{100-x} C_{100}\right)$ at $x=100$ (i), 86 (ii), 75 (iii), 64 (iv), 55 (v), 46 (vi), 36 (vii), 25 (viii), 13 (ix), 8 (x), and 0 (xi) in $4.5 \mathrm{M} \mathrm{NaCl}$. (B) A Lambert-Beer plot to evaluate the TTC-functionalities of $\mathrm{A}_{45} \mathrm{~B}_{\mathrm{x}}\left(\mathrm{B}_{100-\mathrm{x}} \mathrm{C}_{100}\right)$ terpolymers using the PEG-TTC macro-CTA standard.
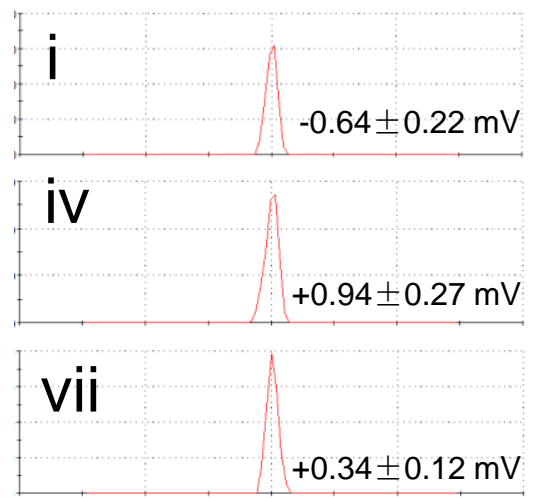

$\mathrm{X}$

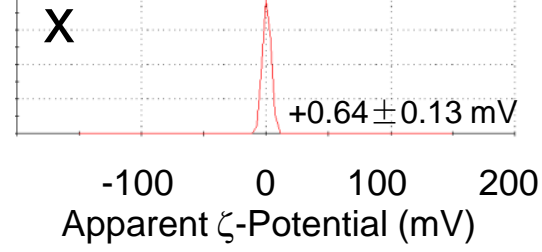

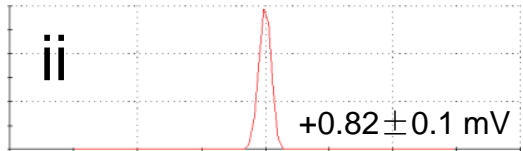
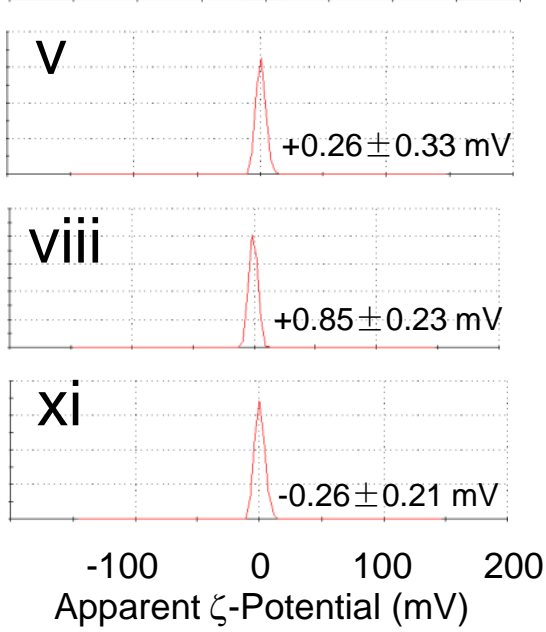
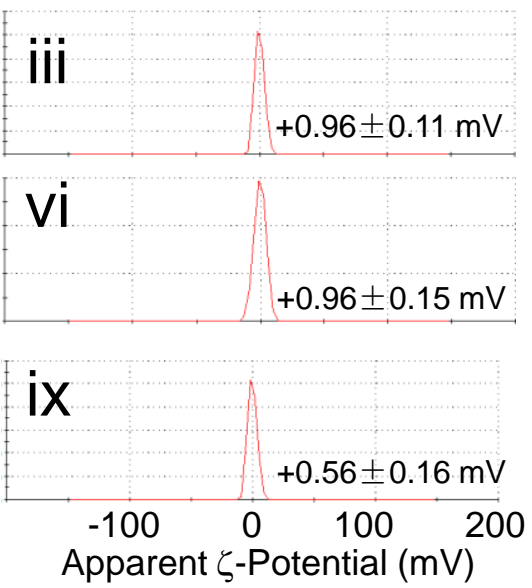

Apparent $\zeta$-Potential (mV)

Figure S13. The $\zeta$-potential results of the $\mathrm{AB}(\mathrm{BC})$-mode PIESA synthesized $\mathrm{A}_{45} \mathrm{~B}_{\mathrm{x}}\left(\mathrm{B}_{100-\mathrm{x}} \mathrm{C}_{100}\right)$ terpolymers at $\mathrm{x}=100$ (i), 86 (ii), 75 (iii), 64 (iv), 55 (v), 46 (vi), 36 (vii), 25 (viii), 13 (ix), 8 (x), and 0 (xi) $(2.0 \mathrm{mg} / \mathrm{mL}$ in water at $\mathrm{pH} 2.5)$.
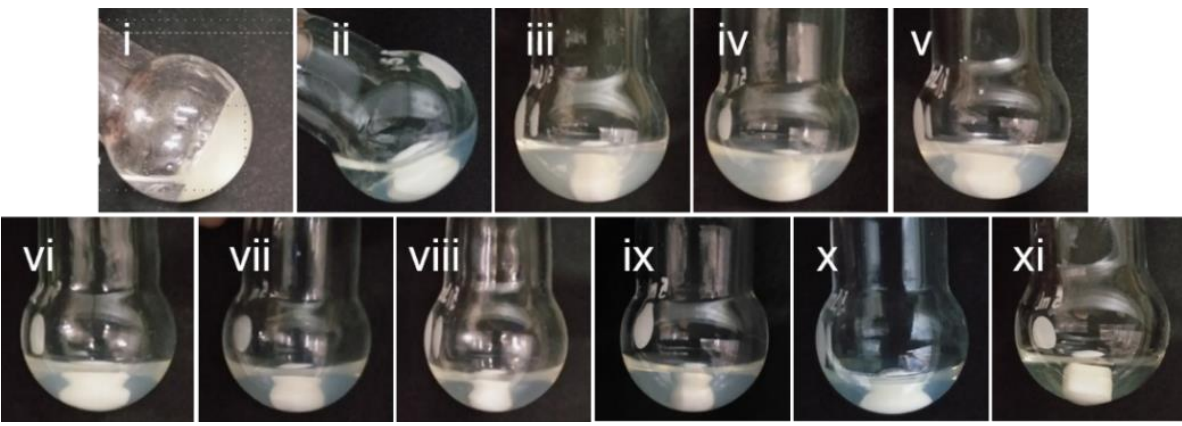

Figure S14. Photographs of resulting dispersions of the $A B(B C)$-mode PIESA synthesized $A_{45} B_{x}\left(B_{100-x} C_{100}\right)$ terpolymers at $x=100$ (i), 86 (ii), 75 (iii), 64 (iv), 55 (v), 46 (vi), 36 (vii), 25 (viii), 13 (ix), 8 (x), and 0 (xi). 

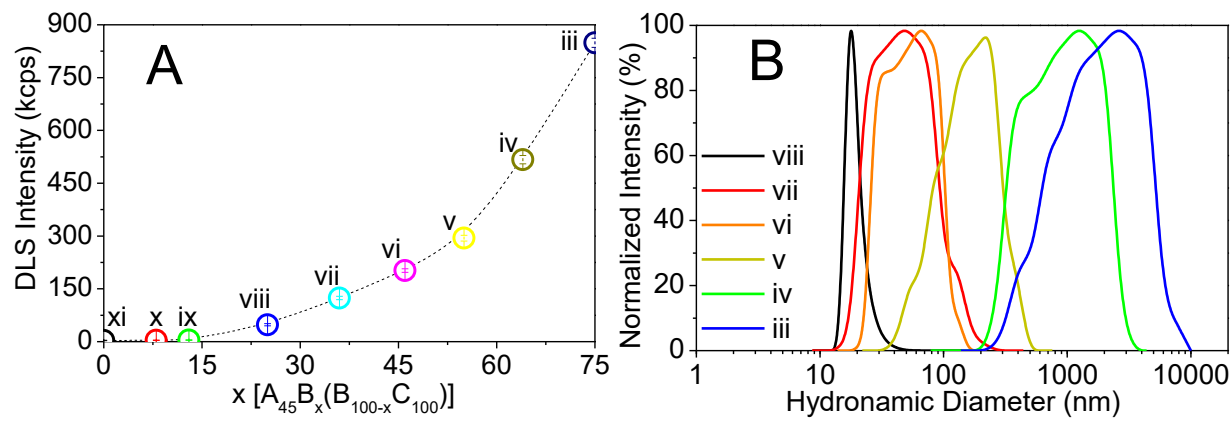

Figure S15. (A) DLS intensity and diameter profiles of the $A B(B C)$-mode PIESA synthesized $A_{45} B_{x}\left(B_{100-x} C_{100}\right)$ terpolymers at $x=75$ (iii), 64 (iv), 55 (v), 46 (vi), 36 (vii), 25 (viii), 13 (ix), 8 (x), and 0 (xi) $(2.0 \mathrm{mg} / \mathrm{mL}$ in water at $\mathrm{pH} 2.5)$.
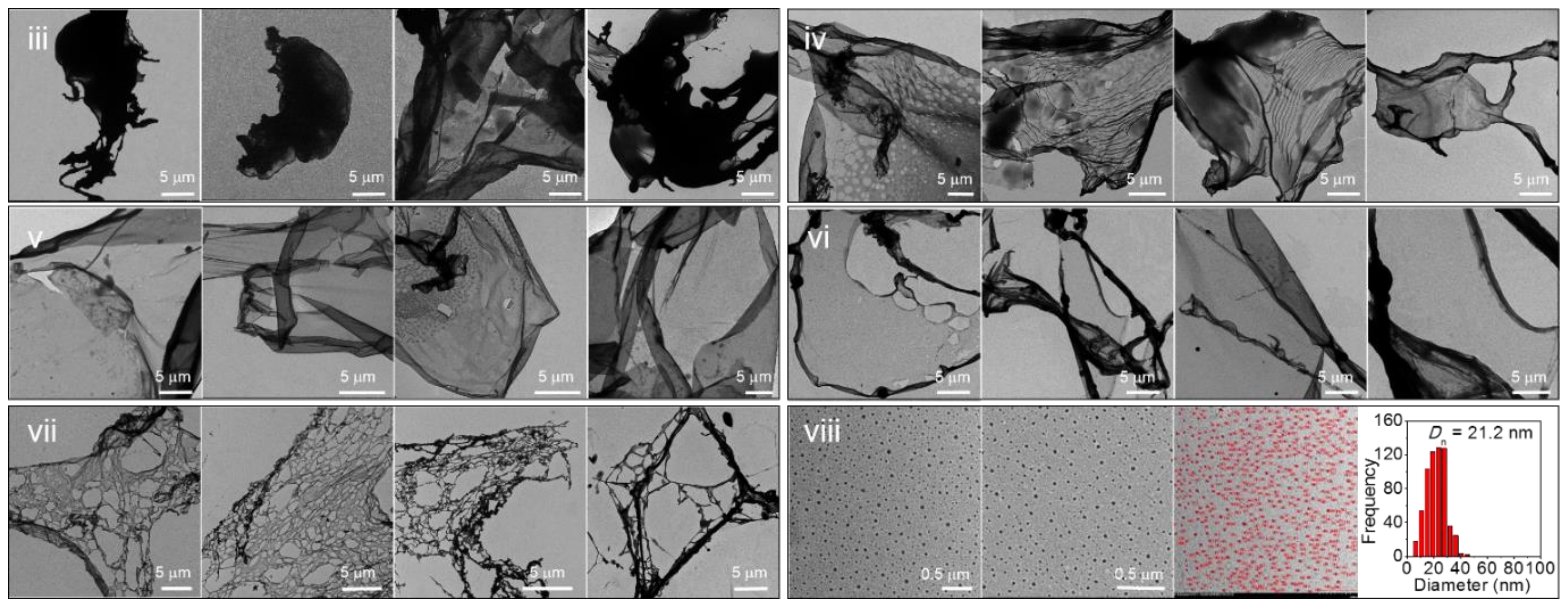

Figure S16. Additional TEM images of the freeze-dried $A B(B C)$-mode PIESA synthesized $A_{45} B_{x}\left(B_{100-x} C_{100}\right)$ particles at $x=75$ (iii), 64 (iv), 55 (v), 46 (vi), 36 (vii), and 25 (viii).

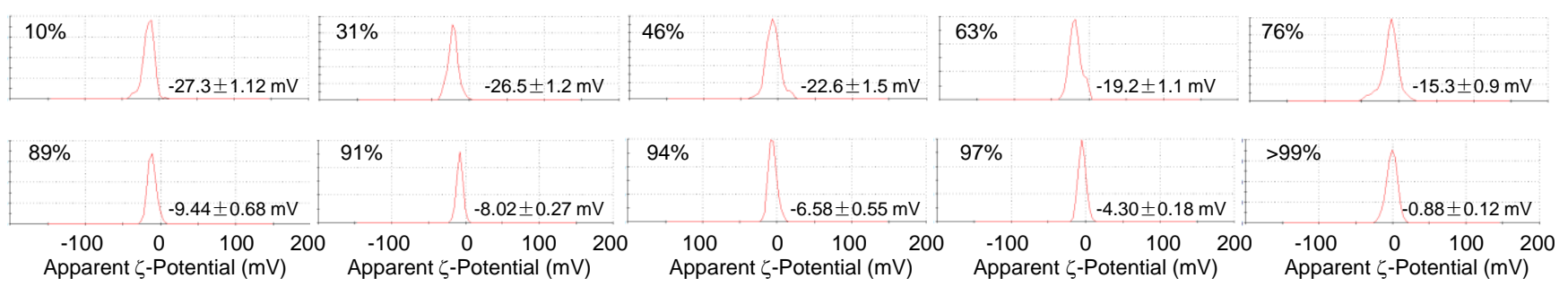

Figure S17. The $\zeta$-potential shift upon zwitterionic copolymerization to $\mathrm{A}_{45} \mathrm{~B}_{75}\left(\mathrm{~B}_{25} \mathrm{C}_{100}\right)$ at labelled AEAM conversions.
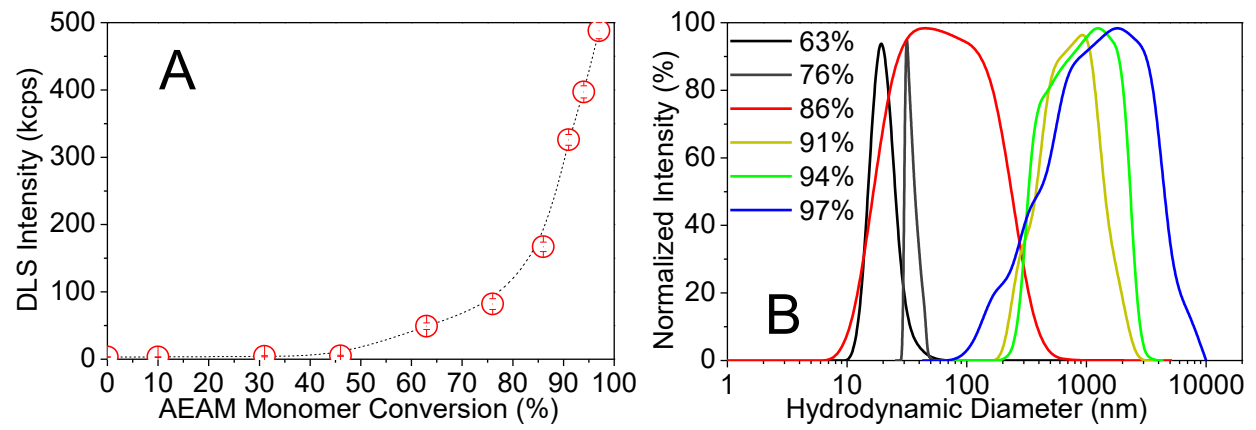

Figure S18. The shift of (A) the DLS intensity of the reactio0n solution and (B) diameter profile of the particles formed during the zwitterionic copolymerization to form $\mathrm{A}_{45} \mathrm{~B}_{75}\left(\mathrm{~B}_{25} \mathrm{C}_{100}\right)$ at labelled $\mathrm{AEAM}$ conversions. 

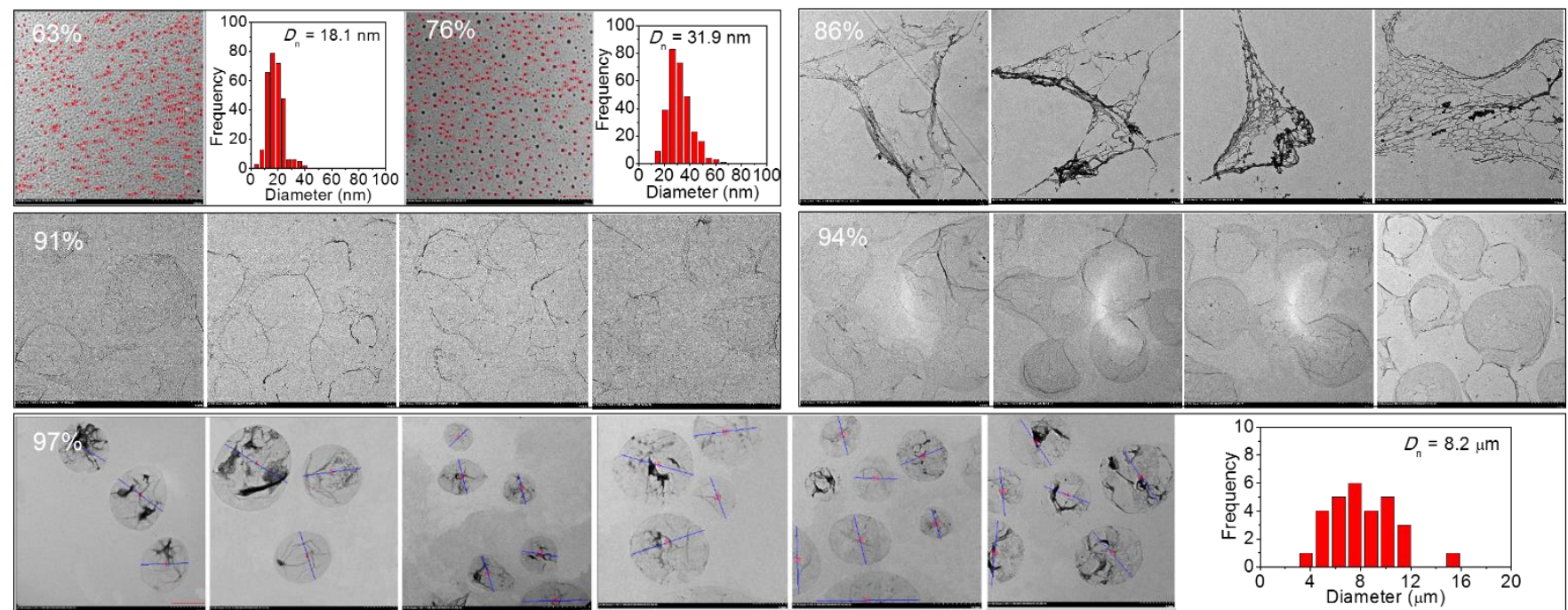

Figure S19. Additional TEM images of freeze-dried particles formed during zwitterionic copolymerization to form $\mathrm{A}_{45} \mathrm{~B}_{75}\left(\mathrm{~B}_{25} \mathrm{C}_{100}\right)$ at labelled $\mathrm{AEAM}$ conversions.
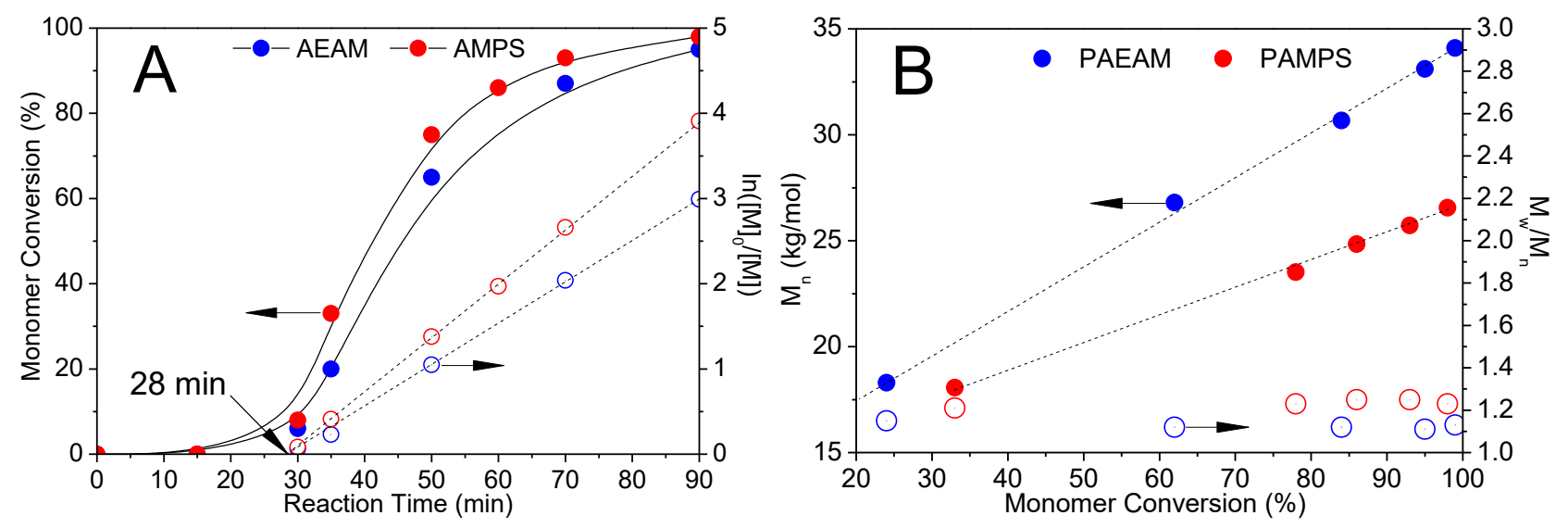

Figure S20. Kinetic results of the homogeneous solution RAFT polymerization of (blue) AEAM and (red) AMPS monomer, at [monomer $]_{0} /[\mathrm{PEG}-\mathrm{TTC}]_{0} /[\mathrm{SPTP}]_{0}=196: 1: 0.25,[\text { monomer }]_{0}=0.80 \mathrm{M}$, in water at $\mathrm{pH} 2.5$ under visible light at $25^{\circ} \mathrm{C}$.
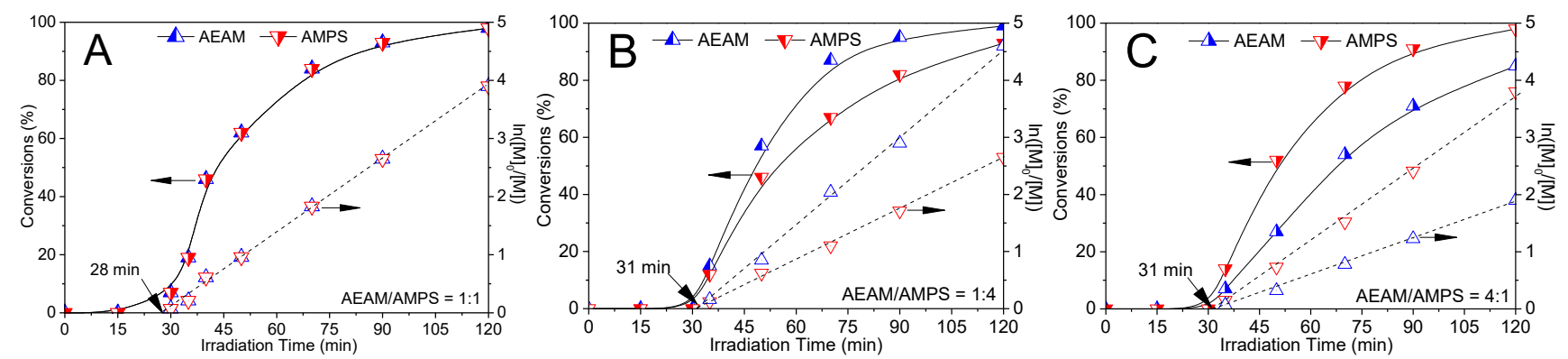

Figure S21. The kinetic plots of homogeneous solution zwitterionic copolymerization of AMPS and AEAM monomers at $[\mathrm{AEAM}]_{0} /[\mathrm{AMPS}]_{0}$ $=1: 1$ (A), $1: 4$ (B), $4: 1$ (C), $[\text { monomers }]_{0} /[\text { PEG-TTC }]_{0} /[\text { SPTP }]_{0}=196: 1: 0.25$, and $[\text { monomers }]_{0}=0.80 \mathrm{M}$, in water pH 2.5 under visible light $25^{\circ} \mathrm{C}$. 


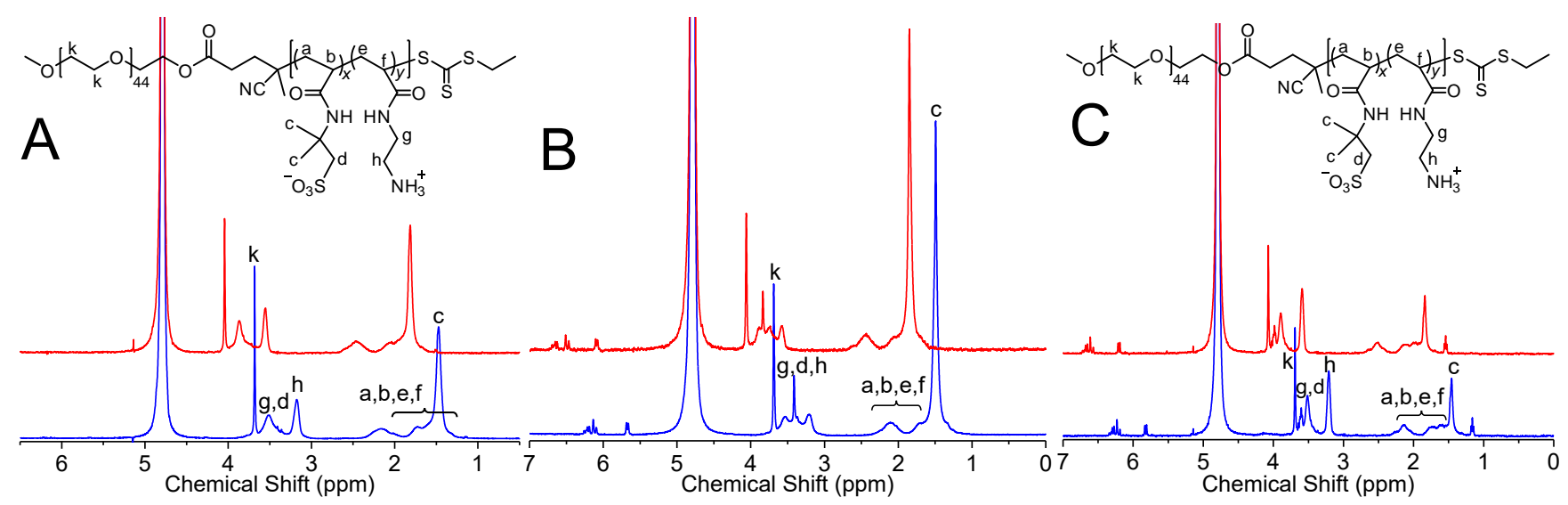

Figure S22. ${ }^{1} \mathrm{H}$ NMR spectra of the zwitterionic terpolymers synthesized via the homogeneous solution copolymerization at $[\mathrm{AEAM}]_{0} /[\mathrm{AMPS}]_{0}=1: 1(\mathrm{~A}), 1: 4(\mathrm{~B}), 4: 1$ (C) described in Figure S20, recorded in (blue) $\mathrm{D}_{2} \mathrm{O}$ and (red) $4.5 \mathrm{M} \mathrm{NaCl}$, pH 2.5. The fully observable signals in these media suggest the excellent aqueous solubility of $(\mathrm{A})$ alternating- and $(\mathrm{B}, \mathrm{C})$ gradient-sequence zwitterionic terpolymers.

\section{References}

(1) Du, J.; Armes, S. P. Preparation of Primary Amine-Based Block Copolymer Vesicles by Direct Dissolution in Water and Subsequent Stabilization by SolGel Chemistry. Langmuir 2008, 24, 13710-13716.

(2) Tong, J.; Shi, Y.; Liu, G.; Huang, T.; Xu, N.; Zhu, Z.; Cai, Y.Visible Light Mediated Fast Iterative RAFT Synthesis of Amino-Based Reactive Copolymers in Water at $20^{\circ} \mathrm{C}$. Macromol. Rapid Commun. 2013,34, 1827-1832.

(3) Xu, X. W.; Smith, A. E.; Kirkland, S. E.; McCormick, C. L. Aqueous RAFT Synthesis of pH-Responsive Triblock Copolymer mPEO-PAPMA-PDPAEMA and Formation of Shell Cross-Linked Micelles. Macromolecules 2008, 41, 8429-8435.

(4) Bronstert, B.; Henne, A.; Hesse, A.; Jacobi, M.; Wallbillich, G., Acylphosphine Compounds and Their Use As Photoinitiators. Patent US 4719297: 1988.

(5) Scales, C. W.; Vasilieva, Y. A.; Convertine, A. J.; Lowe, A. B.; McCormick, C. L. Direct, Controlled Synthesis of the Nonimmunogenic, Hydrophilic Polymer, Poly(N-(2-hydroxypropyl)methacrylamide) via RAFT in Aqueous Media. Biomacromolecules 2005, 6, 1846-1850.

(6) Zhang, B.; Lv, X.; An, Z. Modular Monomers with Tunable Solubility: Synthesis of Highly Incompatible Block Copolymer Nano-Objects via RAFT Aqueous Dispersion Polymerization. ACS Macro Lett. 2017, 6, 224-228. 